\title{
Fungal pathogens associated with young grapevine decline in the Southern Turkey vineyards
}

\author{
D.S. Akgül and M. Ahioğlu \\ Cukurova University, Agriculture Faculty, Department of Plant Protection, 01330 Balcali, Adana, Turkey
}

\begin{abstract}
Young grapevine decline is a common and important disease caused by fungal plant pathogens in Turkey vineyards. Every year many grape growers face this problem in their vineyards and seek solutions to cope with it. The aims of the study were to examine fungal pathogens of young grapevine decline in Southern Turkey and to determine pathogenicity of fungi involved in the disease. Twenty vineyards ( $2-3$ years-old, located in Adana, Mersin and Gaziantep cities) were surveyed in March 2018 and declining whole plants were sampled and processed for mycological procedures. Sub-cultured fungal colonies were examined for colony morphology and conidia-conidiophore shapes under light microscope. For molecular identification, ITS, beta-tubulin, histone and TEF1-alpha gene regions were amplified with PCR using appropriate primers and PCR products were subsequently sequenced. The sequences were compared with those deposited in the NCBI GenBank database using the BLASTn program and fungal identifications were confirmed by getting accession numbers. Pathogenicity tests were fulfilled under greenhouse conditions for two months. The results indicated that Botryosphaeria Dieback and Black Foot fungi were two most common pathogen groups, while Petri Disease and Diaporthe Dieback pathogens had minor incidence. Although a variety of Fusarium species were isolated from declined vines, only $F$. brachygibbosum and $F$. solani were found to have considerable role in disease occurrence.
\end{abstract}

\section{Introduction}

Turkey is an important country among the grape producing countries in the world and it ranks sixth after China in the world grape production. Approximately, 4.1 million tons of grapes are produced in 435.000 ha area in Turkey vineyards [1]. With the expansion of vineyard areas, some phytopathological problems have emerged during the last 50 years in Turkey. Young grapevine decline has been an important disease which encountered in majority of newly established vineyards in Turkey. Failure of grafted materials and dying of newly planted vines are common symptoms in planting year. Stunted and retarded growth, lack of sprouting, chlorotic leaves and dieback are the other symptoms, encountered in subsequent five years [2]. A variety of fungal pathogens including Botryosphaerieaceae fungi, black-foot; Campylocarpon fasciculare, Cylindrodendrum spp., Dactylonectria spp., Neonectria spp. and Ilyonectria spp., Petri Disease; Phaeomoniella chlamydospora and Phaeoacremonium spp., Diaporthe fungi: Diaporthe spp. and Cadophora luteo-olivacea and Pleurostomophora richardsiae have been reported to be associated with young grapevine decline [3-5]. These fungi survive in soil, plant debris or grapevine propagation materials and are mainly transport with infected saplings to many grape growing areas [6]. In case of severe infections, young vines die within 2-5 years and growers face economic losses due to re-planting costs and losing of time.

When young grapevine decline emerged in any vineyard, it is necessary to identify the causal pathogens and to track where disease was originated. A survey study was conducted in commercial grapevine nurseries of Portugal and Ilyonectria liriodendri, Botryosphaeriaceae fungi, Phomopsis viticola and Phaeomoniella chlamydospora were found to be the common species causing young grapevine decline [7]. In another study conducted in California (U.S.), Armillaria mellea, Phytophthora spp., Phaeomoniella chlamydospora, Phaeoacremonium spp. Ilyonectria liriodendri and Verticillium dahliae species were reported as causal agents associated with root rots and young grapevine decline diseases [8].

Up to date, some studies were conducted to manifest fungal pathogens in young grapevines and certain pathogens were recorded in the Aegean and Central Anatolia Region of Turkey. Poyraz and Onogur (2013) surveyed 21 vineyards, younger than 10 years, and they detected Phaeomoniella chlmydospora and Phaeoacremonium aleophilum species leading to Petri Disease in the Aegean Region of Turkey [9]. Akgul et al. (2014) and Gungor-Savas et al. (2015) reported that Campylocarpon fasciculare and Ilyonectria liriodendri were the fungal pathogens responsible for black foot disease of grapevine nurseries in the Aegean Region of Turkey [10,11]. In the Central Anatolia (Turkey), Ilyonectria macrodidyma, Phaeoacremonium scolyti and Pleurostoma richardsiae species were found to be common pathogens associated with young grapevine decline disease [12-14].

The Southern Turkey has the third largest vineyard region and in this region, climate is warmer than that of the Aegean and Central Anatolia Regions. Moreover, there are very few grapevine nurseries in there, so that most of the saplings come from the Aegean Region. In recent years, grape growers have reported that young 


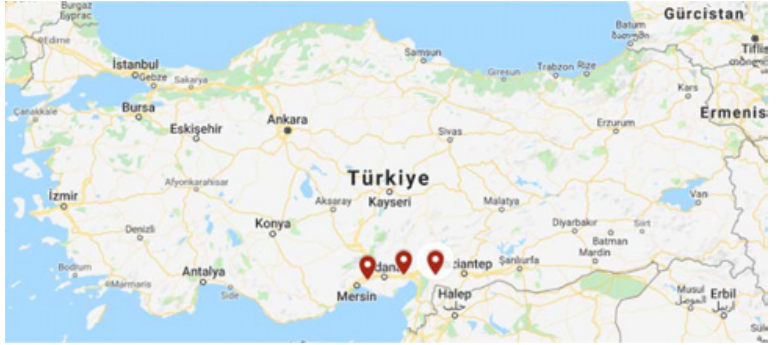

Figure 1. Locations where samples were collected in the Southern Turkey.

grapevine decline has become a common disease in the Southern Turkey vineyards. Up to now, no detailed study was conducted to reveal the fungal pathogens in this region, although some vineyards have been visited and a couple of symptomatic vines were analysed in laboratory. Therefore, a mycological study was arranged to reveal fungal pathogens in the vineyards of this region.

The aims of the study were to determine fungal pathogens associated with young grapevine decline and to understand common species. It was also aimed to raise awareness of the grape growers against the disease.

\section{Material and methods}

\subsection{Sample collection and laboratory studies}

To obtain fungal isolates, 20 vineyards (2-3 years old, located in Adana, Mersin and Gaziantep cities, Fig. 1), having young grapevine decline symptoms, were examined and whole vine samples were uprooted to do laboratory analysis. The samples were taken from local and common table grape varieties (Vitis vinifera cv. Cardinal, Eraly Sweet, Hatun Parmagi, Italia, Prima, Tarsus Beyazi, Yalova Incisi, Victoria) and root, rootstock, graft-union and trunk were separately packed in paper bags.

The samples were washed under running water, briefly dried with paper towels and superficially disinfected with $\mathrm{NaOCl}$ solution (4\%) for 3 minutes, after that they rinsed twice in sterile distilled water and dried with sterile papers under laminar air flow. Tissues $(3-5 \mathrm{~mm})$ were placed on PDA (Potato Dextrose Agar; Merck) amended with streptomycin-sulphate $\left(150 \mathrm{mg} \cdot \mathrm{L}^{-1}\right)$, plates were incubated at $24^{\circ} \mathrm{C}$ for 3 days. After colony growth, mycelia were sub-cultured on PDA, the representative isolates, having different colony morphology, were archived and stored in sterile centrifuge tubes (containing $30 \%$ glycerol-water) at $-20^{\circ} \mathrm{C}$ for further identification studies. Isolation frequency was calculated by counting colonies and proportions of fungal genera were found by dividing colony numbers of each genus to total wood chips in each vineyard. From these data, average isolation rates of the genera (for all regions) were calculated for each different parts of vines (for example: root, rootstock, graftunion and trunk).

\subsection{Morphological and molecular identifications}

In morphological discrimination, colony colour, mycelial growth pattern, conidia and conidiophore shapes, conidiomata and chlamydospore occurrence and picnidial paraphyses were examined under light microscope
(Olympus BX51) and the species were estimated by following the descriptions in literature [15-18].

For molecular identification, DNA was extracted using CTAB extraction protocol, modified by Porebski et al. (1997), their concentration was measured with nanodrop device and final DNA concentration $\left(50 \mathrm{ng} \cdot \mu^{-1}\right)$ was adjusted by dilution with PCR grade water [19]. Universal primer pair ITS4-ITS5 were used to amplify ribosomal DNA regions (rDNA) for all fungal isolates [20]. Additionally, one of the following genes; beta-tubulin, elongation factor (EF) $1-\alpha$ and histone were amplified with Bt2a-Bt2b, EF728F-EF986R and CYLH3F-CYLH3R primers [21-23] using a thermocycler (Applied Biosystems) for identification of some isolates. Each of the PCR reaction tubes contained 10X Thermo Scientific Green PCR buffer ${ }^{\circledR}(2.5 \mu \mathrm{l})$, dNTP mix. $(1 \mu \mathrm{l})$, forward and reverse primers $\left(0.5 \mu \mathrm{l}, 10 \mathrm{pmol} \cdot \mu \mathrm{l}^{-1}\right)$, Thermo Taq polymerase ${ }^{\circledR}$ ( $5 \mathrm{iu}, 0.125 \mu \mathrm{l}$ ), PCR grade water $(19.4 \mu \mathrm{l})$ and target DNA $(1 \mu \mathrm{l})$. The thermocycler was adjusted as follows; $95^{\circ} \mathrm{C}$ for $3 \mathrm{~min}$ (initial denaturation) followed by 35 cycles of denaturation at $95^{\circ} \mathrm{C}$ for $1 \mathrm{~min}$, annealing at $52^{\circ} \mathrm{C}$ for $1 \mathrm{~min}$ (ITS4-ITS5 and EF728FEF986R), $62^{\circ} \mathrm{C}$ for $1 \mathrm{~min}$ (Bt2a-Bt2b), $54^{\circ} \mathrm{C}$ for $1 \mathrm{~min}$ (CYLH3F-CYLH3R), extension at $72^{\circ} \mathrm{C}$ for $1 \mathrm{~min}$ and a final extension $72^{\circ} \mathrm{C}$ for $7 \mathrm{~min}$. After PCR amplification, the products were separated by agarose gel electrophoresis $(1.5 \%)$ in $1 \mathrm{X}$ TAE buffer to check DNA quality. After that, PCR products sequenced (sanger sequencing) and obtained nucleotides were compared with those deposited in the NCBI database using the BLASTn software. For each fungal isolate two different gene sequences were submitted to the GenBank and accession numbers were obtained (Table 1).

\subsection{Pathogenicity tests}

Pathogenicity tests were performed in growth-room conditions $\left(27^{\circ} \mathrm{C}\right.$ stable temp., $12 \mathrm{~h}$ dark/light, $85 \%$ $\mathrm{RH})$ on Cardinal grape saplings. Dormant grapevine cuttings (cv. Cardinal, $30 \mathrm{~cm}$ long, three buds) were taken from vineyard of Plant Protection Dept., University of Cukurova in December 2018. To prevent dehydration, they were immersed into clean tap water at ambient temperature for overnight. After that, cuttings were superficially disinfected with $\mathrm{NaOCl}(2 \%)$ for $2 \mathrm{~min}$, rinsed with sterile distilled water twice and dried in laboratory. Cane internodes were laterally drilled with $2 \mathrm{~mm}$-diameter needle and $2 \mathrm{~mm}$-mycelial plugs (for hardly sporulating fungi) were inserted into cores of the cuttings, or $25 \mu \mathrm{l}$ conidial suspensions $\left(10^{7}\right.$ conidia $\cdot \mathrm{ml}^{-1}$ water) were injected to the holes with a micropipetor, then the holes were sealed with parafilm ${ }^{\circledR}$. The inoculated canes were planted to plastic bags containing growing mixture (fine sawdust, perlite, sand, soil and peat in equal volumes), watered and maintained at growth room conditions (at $28^{\circ} \mathrm{C}$ temp., $90 \%$ relative humidity, $12 \mathrm{~h}$ dark/light) for two months. After this time, cuttings were longitudinally divided with a knife and lesion lengths were measured around inoculation points. To reveal differences between means of the lesion lengths, variance analysis was performed on data and the statistical groups were determined by Fisher's Least Significant Difference (LSD) test at 5\% significance level in all studies [24]. 
Table 1. Lesion lengths in wood tissues of inoculated grapevine plants (Vitis vinifera cv. Cardinal) after two-month incubation.

\begin{tabular}{|c|c|c|}
\hline \multicolumn{2}{|c|}{ Isolate Numbers and Species Names } & $\begin{array}{c}\text { Lesion } \\
\text { Lengths (mm) }\end{array}$ \\
\hline \multicolumn{3}{|c|}{ Adana Isolates } \\
\hline MH136Cyh & Diplodia seriata & $11.9 \pm 0.8 \mathrm{e}^{*}$ \\
\hline MH151Cyh & Fusarium oxysporum & $2.5 \pm 0.2 \mathrm{a}$ \\
\hline MH126Cyh & Fusarium solani & $4.9 \pm 0.5 b$ \\
\hline MH103Cyh & Neofusicoccum parvum & $39.2 \pm 0.1 \mathrm{~m}$ \\
\hline \multicolumn{3}{|c|}{ Gaziantep Isolates } \\
\hline MH146IsL & Fusarium oxysporum & $2.2 \pm 0.1 \mathrm{a}$ \\
\hline MH91IsL & Neofusicoccum parvum & $39.4 \pm 0.4 \mathrm{~m}$ \\
\hline \multicolumn{3}{|c|}{ Mersin Isolates } \\
\hline MH25Trs & Botryosphaeria dothidea & $25.9 \pm 0.4 \mathrm{j}$ \\
\hline MH145Trs & Diporthe ampelina & $25.6 \pm 0.1 \mathrm{j}$ \\
\hline MH143Trs & Diaporthe ampelina & $27.2 \pm 0.6 \mathrm{k}$ \\
\hline MH84Srv & Diplodia seriata & $11.4 \pm 0.1 \mathrm{de}$ \\
\hline MH19Trs & D. seriata & $11.4 \pm 0.5 \mathrm{de}$ \\
\hline MH21Trs & D. seriata & $10.8 \pm 0.4 \mathrm{~d}$ \\
\hline MH137Trs & D. seriata & $11.9 \pm 0.7 \mathrm{e}$ \\
\hline MH261Srv & D. seriata & $12.0 \pm 0.2 \mathrm{e}$ \\
\hline MH40Trs & Dactylonectria macrodidyma & $19.3 \pm 0.3 \mathrm{gh}$ \\
\hline MH116Trs & Dactylonectria torresensis & $17.8 \pm 0.4 \mathrm{f}$ \\
\hline MH153Trs & D. torresensis & $18.6 \pm 0.1 \mathrm{fg}$ \\
\hline MH154Trs & D. macrodidyma & $20.6 \pm 0.5 \mathrm{i}$ \\
\hline MH127Trs & Fusarium brachygibbosum & $8.7 \pm 0.2 \mathrm{c}$ \\
\hline MH111Trs & Fusarium proliferatum & $2.1 \pm 0.5 \mathrm{a}$ \\
\hline MH113Trs & F. proliferatum & $2.3 \pm 0.1 \mathrm{a}$ \\
\hline MH118Trs & F. proliferatum & $2.3 \pm 0.2 \mathrm{a}$ \\
\hline MH94Trs & F. proliferatum & $2.0 \pm 0.6 \mathrm{a}$ \\
\hline MH139Trs & Fusarium oxysporum & $2.2 \pm 0.7 \mathrm{a}$ \\
\hline MH100Trs & Fusarium solani & $4.9 \pm 0.4 b$ \\
\hline MH119Trs & F. solani & $4.8 \pm 0.6 b$ \\
\hline MH134Trs & F. solani & $5.2 \pm 0.1 \mathrm{~b}$ \\
\hline MH12Trs & Lasiodiplodia theobromae & $33.1 \pm 0.21$ \\
\hline MH31Trs & L. theobromae & $33.8 \pm 0.11$ \\
\hline MH45Trs & L. theobromae & $33.1 \pm 0.51$ \\
\hline MH89Trs & Neofusicoccum parvum & $39.2 \pm 0.3 \mathrm{~m}$ \\
\hline MH90Trs & N. parvum & $39.0 \pm 0.4 \mathrm{~m}$ \\
\hline MH121Trs & N. parvum & $39.0 \pm 0.2 \mathrm{~m}$ \\
\hline MH108Trs & Phaeoacremonium minimum & $19.6 \pm 0.4 \mathrm{~h}$ \\
\hline MH115Trs & Phaeoacremonium minimum & $18.9 \pm 0.4 \mathrm{gh}$ \\
\hline MH114Trs & $\begin{array}{c}\text { Pleurostomophora } \\
\text { richardsiae }\end{array}$ & $11.2 \pm 0.4 \mathrm{de}$ \\
\hline \multicolumn{2}{|c|}{ Un-inoculated Control } & $1.7 \pm 0.2 \mathrm{a}$ \\
\hline
\end{tabular}

* Mean values within a column are significantly different at the 0.05 level based on LSD test. Mean values correspond to the extent of wood discoloration measured upward and downward from the point of inoculation.

\section{Results and discussion}

\subsection{Isolation and identification results}

Totally 36 fungal isolates were obtained from the 20 vineyards in the Southern Turkey Region. 15 isolates were belonged in Botryosphaeriaceae fungi, 12 isolates were from Fusarium genus, four of them from black-foot, two were from Petri Disease, and Diaporthe Dieback, and one isolate was Pleurostomophora richardsiae.

Botryosphaeriaceae were the most frequently isolated fungi, so that they could be isolated from all parts of the symptomatic, declined vines. The isolation rates were $36.8 \%, 30.8 \%, 20 \%$ and $4.9 \%$ from the trunk, graftunion, rootstock and roots respectively. Following that Fusarium was the second commonly isolated genus from the roots and the other parts of the vines with $26.7 \%$, $14.7 \%, 7.4 \%$ and $11.4 \%$ rates (from bottom to top). Besides that, black-foot fungi were also found from all parts of the vines but maximum incidence (35.2\%) was recorded from the root tissues. The incidence of this fungi decreased below $10 \%$ as going up from the roots to trunk. On the contrary, Petri Disease pathogens could not be isolated from all examined sections of the vines and it was found just in rootstock tissues with the minimum incidence $(0.8 \%)$. Diaporthe was another genus which was found in most of the parts (except roots) in vines but its incidence was lower (minimum: $2.2 \%$ and maximum: $6.3 \%$ ) than that of Botryosphaeriaceae and Fusarium fungi (Fig. 2). According to morphological-microscopic examinations and molecular methods, four different species of Botryosphaeriaceae fungi (Botryosphaeria dothidea, Diplodia seriata, Lasiodiplodia theobromae and Neofusicoccum parvum), four species of Fusarium (F. barchygibbosum, F. oxysporum, F. proliferatum and F. solani), two species of Dactylonectria (D. macrodidyma, D. torresensis), Diaporthe ampelina, Phaeoacremonium minimum and Pleurostomophora richardsiae were identified and their species names were confirmed by recording sequences to the NCBI GenBank with accession numbers (Table 2). On the other hand, a variety of endophytic species (Alternaria, Aspergillus, Penicillium Rhizopus sp. etc.) and Clonostachys rosea (potential biocontrol agent) were detected from the young vines but no GenBank numbers were obtained for these fungi.

\subsection{Pathogenicity tests results}

The fungal isolates included in pathogenicity tests produced lesions (generally blackish-brown streaks), which their lengths ranging from 2.0 to $39.4 \mathrm{~mm}$, in wood tissues of the inoculated grapevine plants within two months. In control plants treated with sterile water, average $1.7 \mathrm{~mm}$ brown lesions were occurred but most of the isolates lead to significantly longer streaks than that of control. Two members of Botryosphaeriaceae fungi (Neofusicoccum parvum and Lasiodiplodia theobromae) lead to longest lesions in inoculated plants, so that the lesion lengths of these species ranged between 33.1 and $39.4 \mathrm{~mm}$. $N$. parvum was more virulent than $L$. theobromae. In this family, Diplodia seriata and Botryosphaeria dothidea could not show remarkable virulence as observed in the former two species. Considering the other lesion lengths, Diaporthe ampelina, Dactylonectria torresensis, Dactylonectria macrodidyma, Phaeoacremonium minimum and Pleurostomophora richardsiae were classified the other species following $N$. parvum and L. theobromae.

On the other hand, Fusarium isolates were not so successful in producing symptomatic wood streaks, when compared the other pathogen groups. The average lesion lengths produced by Fusarium oxysporum and 

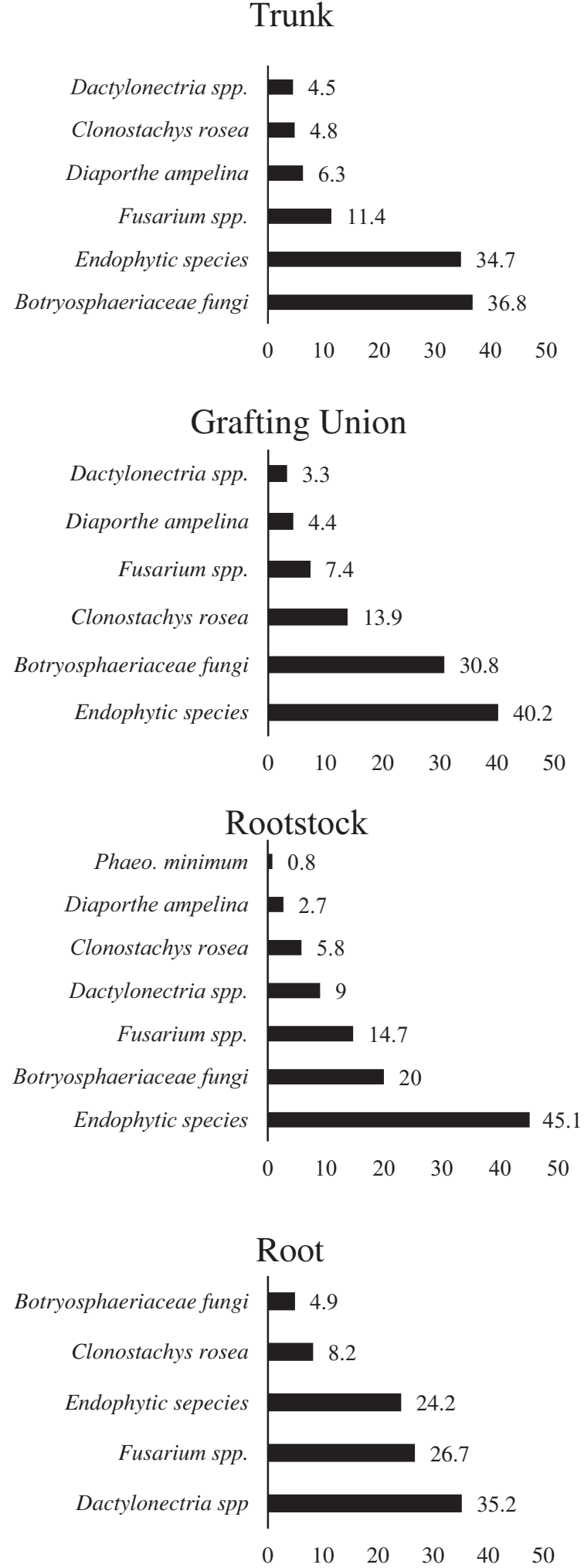

Figure 2. Isolation rates (\%) of fungi from different parts of symptomatic vines in the vineyards sampled.

F. proliferatum were not different from those produced by sterile water statistically. However, longer lesions were recorded when grapevine cuttings were inoculated with $F$. brachygibbosum and $F$. solani. According to these results, it can be concluded that $F$. oxysporum and $F$. proliferatum isolates were not to be pathogenic but $F$. brachygibbosum and $F$. solani were pathogenic on grapevines (Table 1).
Aroca et al. (2006) surveyed 13 young vineyards (one-year old) in Spain and conducted a study to reveal main fungal pathogens causing decline symptoms. 208 plants were collected in 2002-2004 years, of which 94 plants (45.2\%) were found to be infected with Phaeomoniella chlamydospora, Phaeoacremonium, Botryosphaeria, Ilyonectria and Phomopsis species [25]. In another study conducted in Italy (2013-2015 years), totally 45 young grapevine plants (aged from 12-18 months) were examined and Petri Disease, Botryosphaeria Dieback and Black Foot pathogens were isolated. Some of the species (Phaeoacremonium minimum, Pleurostoma richardsiae, Diplodia seriata, Lasiodiplodia theobromae, Neofusicoccum parvum and Dactylonectria torresensis) isolated in this research were the same with that we isolated in our study. So our findings corroborate the results of Carlucci et al. (2017) [26].

Pintos et al. (2018) determined the phytosanitary status of grapevine nurseries (2 in Spain, 1 in France) by analysing 150 young grapevine plants. From 449 fungal isolates, five species of Botryosphaeria Dieback, six from Black Foot Disease, six from Diaporthe Dieback and three species from Petri Disease have been characterized [27].

Botryosphaeriaceae fungi have been frequently obtained from symptomatic young grapevines and they have been considered to have an important role in disease occurrence [28]. These fungi can be found in any asymptomatic propagation material as an endophyte or latent pathogen and can easily be disseminated to large areas [29]. In the current study, high incidence percentages of Botryosphaeriaceae indicate that these fungi were highly prevalent in all parts of the symptomatic vines and most of the propagation materials were thought to be contaminated as a latent infection in the Southern Turkey vineyards. Climate is a critical factor influencing geographical distribution of this fungi [30]. While the climate is mild and rainy (average precipitation; $750 \mathrm{~mm}$. year $\left.^{-1}\right)$ in winters, it is very hot $\left(34-42^{\circ} \mathrm{C}\right)$ during summer in this region. Hot weather and water stress have been shown to contribute disease development by Botryosphaeriaceae pathogens [31]. These factors may be one of the reasons for the high level of disease incidence in Southern Turkey.

Black foot fungi were the second group having high percentage incidence in that region. Interestingly, they have been isolated from the roots to trunks of sampled plants. It has been demonstrated that inoculum of black foot pathogens was found at different stages of vine nursery propagation process and suggested that these pathogens could infect plant tissues during vine production process [32]. The reasons why these fungi were found in all processed tissues during laboratory studies could be related with these events. There are a few grapevine nurseries in the Southern Turkey and most of the grafted plants are brought from the Aegean Region where many commercial nurseries are found. Therefore, most of the black foot pathogens was thought to contaminate the Southern vineyard areas from the Aegean Region, Turkey. Dactylonectria species can survive in soil as chlamydospore and infect newly planted vines from their roots [33]. Root infections are important and may be responsible for disease incidence. However, we could not see decline symptoms in the vineyards established on their own roots that we visited. 
Table 2. Fungal species obtained from the isolate collection study in the Southern Turkey vineyards.

\begin{tabular}{|c|c|c|c|c|c|c|}
\hline \multirow{2}{*}{\multicolumn{2}{|c|}{ Isolate Numbers and Species Names }} & \multirow{2}{*}{$\begin{array}{l}\text { Host } \\
\text { (Vitis viniferacv.) }\end{array}$} & \multicolumn{4}{|c|}{ GenBank Accession Numbers } \\
\hline & & & ITS & Beta-tubulin & TEF1- $\alpha$ & Histone H3 \\
\hline \multicolumn{7}{|c|}{ Adana Isolates } \\
\hline MH136Cyh & Diplodia seriata & 5BB-Italia & MK817029 & - & MK838563 & - \\
\hline MH151Cyh & Fusarium oxysporum & 1103P-Victoria & MK817030 & - & MK838564 & - \\
\hline MH126Cyh & Fusarium solani & 1103P-Cardinal & MK817031 & - & MK838565 & - \\
\hline MH103Cyh & Neofusicoccum parvum & 1103P-Cardinal & MK817032 & - & MK838566 & - \\
\hline \multicolumn{7}{|c|}{ Gaziantep Isolates } \\
\hline MH146IsL & Fusarium oxysporum & 5BB-Hatun Parmagi & MK817033 & - & MK838567 & - \\
\hline MH91IsL & Neofusicoccum parvum & 5BB-Hatun Parmagi & MK817034 & - & MK838568 & - \\
\hline \multicolumn{7}{|c|}{ Mersin Isolates } \\
\hline MH25Trs & Botryosphaeria dothidea & 1103P-Victoria & MK817035 & - & MK838569 & - \\
\hline MH145Trs & Diporthe ampelina & 5BB-Yalova Incisi & MK817037 & MK838571 & - & \\
\hline MH143Trs & Diaporthe ampelina & SO4-Victoria & MK817036 & MK838570 & - & - \\
\hline MH84Srv & Diplodia seriata & 1103P-Prima & MK817040 & - & MK838574 & - \\
\hline MH19Trs & D. seriata & 110R-Yalova Incisi & MK817041 & - & MK838575 & - \\
\hline MH21Trs & D. seriata & 110R-Victoria & MK817042 & - & MK875258 & - \\
\hline MH137Trs & D. seriata & Tarsus Beyazi & MK817038 & - & MK838572 & - \\
\hline MH261Srv & D. seriata & 1103P-Victoria & MK817039 & - & MK838573 & - \\
\hline MH40Trs & Dactylonectria macrodidyma & 1103P-Prima & MK817043 & MK875273 & - & MK955244 \\
\hline MH116Trs & Dactylonectria torresensis & 1103P-Victoria & MK817044 & MK875274 & - & MK955245 \\
\hline MH153Trs & D. torresensis & 1103P-Prima & MK942432 & MK875276 & - & MK955246 \\
\hline MH154Trs & D. macrodidyma & 1103P-Victoria & MK942433 & MK875277 & - & MK955247 \\
\hline MH127Trs & Fusarium brachygibbosum & 1103P-Victoria & MK817053 & - & MK875267 & - \\
\hline MH111Trs & Fusarium proliferatum & 1103P-Early Sweet & MK817046 & - & MK875260 & - \\
\hline MH113Trs & F. proliferatum & 1103P-Victoria & MK817047 & - & MK875261 & - \\
\hline MH118Trs & F. proliferatum & 1103P-Prima & MK817048 & - & MK875262 & - \\
\hline MH94Trs & F. proliferatum & Tarsus Beyazi & MK817049 & - & MK875263 & - \\
\hline MH139Trs & Fusarium oxysporum & 1103P-Victoria & MK817045 & - & MK875259 & - \\
\hline MH100Trs & Fusarium solani & 1103P-Early Sweet & MK817050 & - & MK875264 & - \\
\hline MH119Trs & F. solani & 5BB-Yalova Incisi & MK817051 & - & MK875265 & - \\
\hline MH134Trs & F. solani & 1103P-Victoria & MK817052 & - & MK875266 & - \\
\hline MH12Trs & Lasiodiplodia theobromae & Tarsus Beyazi & MK817054 & - & MK875268 & - \\
\hline MH31Trs & L. theobromae & 1103P-Early Sweet & MK817055 & - & MK875269 & - \\
\hline MH45Trs & L. theobromae & 1103P-Victoria & MK817056 & - & MK875259 & - \\
\hline MH89Trs & Neofusicoccum parvum & 1103P-Prima & MK817058 & - & MK875271 & - \\
\hline MH90Trs & N. parvum & 1103P-Early Sweet & MK817059 & - & MK875272 & - \\
\hline MH121Trs & N. parvum & 5BB-Yalova Incisi & MK817057 & - & MK875270 & - \\
\hline MH108Trs & Phaeoacremonium minimum & 1103P-Victoria & MK817061 & MK875275 & - & - \\
\hline MH115Trs & Phaeoacremonium minimum & 5BB-Yalova Incisi & MK817062 & - & MK955243 & - \\
\hline MH114Trs & Pleurostoma richardsiae & 1103P-Prima & MK817060 & - & MK955242 & - \\
\hline
\end{tabular}

The pathogenicity of some Fusarium isolates that we isolated from the symptomatic vines demonstrates that these fungi could contribute to disease occurrence. In a study conducted in Canada, five Fusarium species (Fusarium sp. F. oxysporum, F. proliferatum, F. solani and $F$. ramigenum) were isolated from declined vines and their role on disease incidence were investigated with pathogenicity tests. Results indicated that these species caused root necrosis similar to those observed by Dactylonectria pauciceptata, D. macrodidyma and Ilyonectria liriodendri and have an important role on young grapevine health [34].

This study showed that some of the fungal pathogens grouped in grapevine trunk diseases (GTD) were responsible for young grapevine decline occurrence in the Southern Turkey vineyards. Isolation of GTD pathogens (more than one) from the same plant indicates that grapevine saplings have been infected with these fungi 
during propagation process in the nurseries. Therefore, grapevine sapling producers should follow cultural, physical, biological and chemical management practices to reduce young grapevine decline incidence and to produce healthier plants.

This study was supported by Cukurova University Scientific Research Projects Department under project number; FYL-201810643 and it was a MsC Thesis Project. We thank The Rectorate of Cukurova University.

\section{References}

[1] TUIK, The official website of Turkish Statistical Institute. Accession Date: 23.04.2019

[2] J.A. Stamp, Phytopathol. Mediterr. 40, 369 (2001)

[3] H.J. Scheck, S.J. Vasquez, D. Fogle, W.D. Gubler, Calif. Agric. 52, 19 (1998)

[4] B.E. Overton, E.L. Stewart, N.G. Wenner, Phytopathol. Mediterr. 44, 90 (2005)

[5] P.E. Rolshausen, W. Wilcox, K. Baumgartner, Phytopathol. Mediterr. 49, 105 (2010)

[6] H. Waite, M. Cole, G. Jaudzems, J. Faragher, Aust. New Zeal. Grape. Wine. 485, 39 (2004)

[7] C. Rego, T. Nascimento, A. Cabral, M.J. Silva, H. Oliviera, Phytopathol. Mediterr. 48, 125 (2009)

[8] W.D. Gubler, K. Baumgartner, G.T. Browne, A. Eskalen, S. Rooney, E. Petit, L.A. Bayramian, Australas. Plant Pathol. 33, 157 (2004)

[9] D. Poyraz, E. Onogur, Turk J. Plant Pathol. 1, 13 (2013)

[10] D.S. Akgul, N.G. Savas, A. Eskalen, Plant Dis. 98, 568 (2014)

[11] N.G. Savas, D.S. Akgul, E.A. Albaz, Plant Dis. 99, $1855(2015)$

[12] S. Özben, F. Demirci, K. Degirmenci, S. Uzunok, Plant Dis. 96, 762 (2012)

[13] S. Özben, K. Degirmenci, F. Demirci, S. Uzunok, Plant Dis. 96, 766 (2012)

[14] S. Özben, F. Demirci, K. Degirmenci, S. Uzunok, J. Plant Pathol. 99, 804

[15] P.E. Nelson, T.A. Tousson, W.F.O. Marasas, Fusarium Species (The Pennsylvania State Univrsity Press, 1983)
[16] A.J.L. Phillips, A. Alves, J. Abdollahzadeh, B. Slippers, M.J. Wingfield, J.Z. Groenewald, P.W. Crous, Studies in Mycol. 76, 51 (2013)

[17] L. Mostert, J.Z. Groenewald, R.C. Summerbell, W. Gams, P.W. Crous, Stud. Mycol. 54, 1 (2006)

[18] L. Lombard, N.A. Van Der Merwe, J.Z. Groenewald, P. Crous, Phytopathol. Mediterr. 53, 515 (2014)

[19] S. Porebski, L.G. Bailey, B.R. Baum, Plant Mol. Biol. Rep. 15, 8 (1997)

[20] T.J. White, T. Burns, S. Lee, J. Taylor, PCR protocols: A guide to methods and applications, 1990

[21] N.L. Glass, G.C. Donaldson, Appl. Env. Microbiol. 61, 1323 (1995)

[22] I. Carbone, L.M. Kohn, Mycologia, 91, 553 (1999)

[23] P.W. Crous, J.Z. Groenewald, J.M. Risede, P. Simoneau, N.L. Hywel-Jones, Studies in Mycol. 50, 415 (2004)

[24] K.A. Gomez, A.A. Gomez, Statistical Procedures for Agricultural Research (Wiley, 1984), p. 684

[25] A. Aroca, F.G. Figueres, L. Bracamonte, J. Luque, R. Raposo, Eur. J. Plant Pathol. 115, 195 (2006)

[26] A. Carlucci, F. Lops, L. Mostert, F. Halleen, M.L. Raimondo, Phytopathol. Mediterr. 56, 10 (2017)

[27] C. Pintos, V. Redondo, D. Costas, O. Aguin, P. Mansilla, Phytopathol. Mediterr. 57, 407 (2018)

[28] A. Jaime-Gimenez, A. Aroca, R. Raposo, J. GarciaJimenez, J. Armengol, J. Phytopathol. 154, 598 (2006)

[29] B. Slippers, M.J. Wingfield, Fungal Biol. Rev. 21, 90 (2007)

[30] J.R. Ubez-Torres, G.M. Leavitt, J.C. Guerrero, J. Guevara, W.D. Gubler, Plant Dis. 92, 519 (2008)

[31] J. Luque, S. Martos, F. Garcia-Fiqueres, Phytopathol. Mediterr. 49, 120 (2010)

[32] C. Agusti-Brisach, J. Armengol, Phytopathol. Mediterr. 52, 245

[33] F. Halleen, H.J. Schoers, J.Z. Groenewald, P.W. Crous, Studies in Mycol. 50, 431 (2004)

[34] J.R. Urbez-Torres, J. Boule, D.T. O'Gorman, Proceedings of $10^{\text {th }}$ IWGTD (2017), p. 527 